\title{
The Significance of Social Welfare Attitudes in Young People's Entrepreneurial Intentions
}

\author{
Teemu Rantanen, Agnieszka Pawlak, Timo Toikko
}
Objective: The present study analyses young people's entrepreneurial intentions in Finland and Poland. Previous surveys have shown that the desire to become an entrepreneur is stronger in between Polish people than in between Finnish people.

A B S TRACT

Research Design \& Methods: By exploring the social psychological factors that explain young people's entrepreneurial intentions, the study particularly sought to determine whether the differences in entrepreneurial intention can be explained by social welfare attitudes. Survey respondents were 725 Finnish and 887 Polish students.
\end{abstract}

Findings: Finnish and Polish young people approach entrepreneurship in quite different ways. Finnish young people appreciate entrepreneurs at a general level, but do not consider becoming entrepreneurs themselves, while the Poles think about entrepreneurship in the opposite manner. Furthermore, the results show that Finnish people's trust in society is much stronger than that of their Polish counterparts.

Implications \& Recommendations: Influencing young people's confidence in their abilities and skills is more important than trying to influence general attitudes about entrepreneurship. Thus, entrepreneurship education has a key role in supporting young people's entrepreneurship. National differences in intentions and in appreciation of entrepreneurship can be explained by societal and historical factors.

Contribution \& Value Added: Entrepreneurial intention is typically explained by psychological, economic, and cultural factors, and by social capital. Study results show that social political factors are also important in explaining entrepreneurial intentions.

\section{Article type: research paper \\ Keywords: \\ entrepreneurial intention; Theory of Planned Behaviour; social attitudes; social welfare}

JEL codes: L26, Z11

Received: 12 October $2014 \quad$ Revised: 17 February $2015 \quad$ Accepted: 24 February 2015

\section{Suggested citation:}

Rantanen, T., Pawlak A., \& Toikko, T. (2015). The Significance of Social Welfare Attitudes in Young People's Entrepreneurial Intentions. Entrepreneurial Business and Economics Review, 3(1): 43-60, DOI: http://dx.doi.org/10.15678/EBER.2015.030104. 


\section{INTRODUCTION}

The importance of entrepreneurship, which is considered a core factor in the competitiveness of a society, national economy, and regional development, has been highlighted in many recent resolutions in Europe. Moreover, the significance of entrepreneurship has been underlined as a means of employment at individual level. At the same time, the promotion of entrepreneurship and entrepreneurship education has emerged as an important societal effort.

Considerable research activity in the field of entrepreneurship education has been conducted since the early 1980s (Kuratko, 2005). Within the context of entrepreneurship education and new-venture creation, the concept of entrepreneurial intention plays a central role. In the Shapero-Krueger model, intention is explained by perceived desirability and perceived feasibility (Krueger et al., 2000). According to several studies, Ajzen's $(1991,2001)$ theory of planned behaviour has been effective in explaining entrepreneurial intention and activity (e.g., Goethner, Obschonka, Silbereisen \& Cantner, 2012; Liñán, 2008; Liñán \& Chen, 2009; Moriano, Gorgievski, Laguna, Stephan \& Zarafshani, 2012; Walker, Jeger \& Kopecki, 2013).

Many cultural and economic factors have an impact on entrepreneurial intention and entrepreneurship. According to Mueller and Thomas (2001), a supportive national culture will, all things being equal, increase the entrepreneurial potential of a country. In particular, the importance of individualism is highlighted in terms of entrepreneurial intention (e.g., Liñán \& Chen, 2009; Mitchell, Smith, Seawright \& Morse, 2000; Siu \& Lo, 2013). However, Tiessen (1997) argues that, while individualistic values lead to new venture creation and innovation, collectivist values allow a firm to leverage its resources.

According to Global Entrepreneurship Monitor (GEM) study, an explanation of national differences in entrepreneurial intention refers to differences between innovation-driven economies and efficiency-driven economies (Xavier, Roland, Jacqui, Herrington \& Vorderwulbecke, 2013). Noorderhaven, Thurik, Wennekers \& van Stel (2004) found that GDP per capita has a negative impact on self-employment, while many researchers have argued that entrepreneurial activities are based on the common effects of cultural, social, and economic factors (e.g., Freytag \& Thurik, 2007; Lee \& Peterson, 2000). Fitzsimmons and Douglas (2005) particularly emphasize the impact of low percapita income, individualism, and lower scores on Hofstede's Uncertainty Avoidance Index. Additionally, Mueller (2004) explains entrepreneurial potential by gender, by the cultural dimensions of Hofstede (1980), and by GDP per capita.

Many researchers have highlighted the importance of social capital. According to Liñán and Santos (2007), social capital affects entrepreneurial intention via perceived desirability and perceived feasibility. Goethner et al. (2012) suggest that social capital along with public support institutions has a direct impact on academic entrepreneurial intention. Chuluunbaatar, Ottavia \& Kung (2011) have analysed common effect of social capital and entrepreneurial intention on entrepreneurial orientation.

In contrast, the impact of social political factors has been studied rarely. However, based on the GEM study, one could suppose that these factors are also important from the perspective of entrepreneurial intention. European comparisons show that entrepreneurial intention is high in many post-communist Eastern European countries 
(e.g., Romania, Poland, Latvia, Bosnia-Herzegovina, and Macedonia) and low in many Nordic welfare states (e.g., Norway, Denmark, and Finland) (Xavier et al., 2013, p. 21).

This study focuses on the phenomenon of entrepreneurial intention in two different countries: Finland and Poland. The theoretical perspective of the study is based on attitude research, in particular Ajzen's $(1991,2001)$ theory of planned behaviour, and on discussion about welfare states (Esping-Andersen, 1990). The significance of social welfare attitudes, in terms of entrepreneurial intentions and entrepreneurial attitudes in Finland and Poland, was analysed. The research data was collected from among Finnish $(N=725)$ and Polish $(N=887)$ young people.

\section{LITERATURE REVIEW}

\section{Societal Context in Finland and Poland}

According to the GEM study mentioned previously, Poland is an efficiency-driven economy, while Finland is an innovation-driven economy. Entrepreneurial intentions differ significantly between these two countries: $68 \%$ of Polish and only $45 \%$ of Finnish young people see entrepreneurship as a good career choice (the average in the European Union is 58\%). Conversely, in Finland, the status of successful entrepreneurs is the highest in the European Union; in Poland, however, it is below the European average (Xavier et al., 2013, p. 21.)

In the social policy and social historic contexts, Finland and Poland represent different kinds of societies. Finland is a wealthy Nordic welfare state that offers universal social security to its citizens, while Poland is a post-communist nation that emphasizes a civil society in its social policy. According to Freytag \& Thurik's (2007) comparative study, the communist history of a country has a negative effect on the preference for entrepreneurship, but no effect on actual entrepreneurship.

In general terms, the differences between the Finnish and Polish societies also relate to different types of welfare states. The classical analysis by Esping-Andersen (1990) makes explicit the differences between three welfare state regimes - Anglo-American, Nordic, and Continental - and it is argued that Mediterranean welfare states should be viewed as a fourth type (Moreno, 2010). Similarly, the new Central-East European (postcommunist) states can be seen as having their own type of welfare state (Aidukaite, 2009). The various types of welfare states differ from each other, particularly from the perspective of social responsibility and social trust.

The Nordic and Continental models emphasize the state's responsibility for welfare, but the Anglo-American model underlines the responsibility of individuals, families, and communities. In particular, the Nordic welfare state strives to create the best possible society by providing everyone with equal opportunities for education and healthcare (Alestalo, Hort, \& Kuhnle, 2009; Alestalo \& Kuhnle, 1987). The Nordic welfare state is grounded on the notion of universal welfare services and a regulated labor market (Anttonen \& Sipilä, 2012). The Anglo-American model underlines the role of citizenship in providing welfare (Fitzpatrick, 2011). This means that citizens have to be active in their communities and in the labor market to guarantee welfare (Andreotti, Mingione \& Polizzi, 2011). Similarly, it is argued that the Central-East European countries have given citizens more responsibilities in providing welfare and well-being (cf. Draxler \& Van Vliet, 
2010), although their states traditionally played a strong role during the former communist regimes.

In this study, Finland represents a country in which the state has the main responsibility for welfare, and Poland represents a country in which citizens are primarily responsible for their own welfare. Among scholars, there is a shared notion that countries with a greater state responsibility for citizens' welfare do not have as much space for citizen-based activities as countries with less responsibility (cf. Fitzpatrick, 2011; Le Grand, 2003, 2010). Indirectly, this suggests that entrepreneurial intentions are weaker in countries in which the state and government bear the responsibility for the citizens' welfare and well-being.

On the other hand, countries in which the state has the principal responsibility for providing welfare are stable, Kumlin \& Rothstein (2005) argue that welfare states produce mutual trust among their people. According to comparative studies, Finland and the other Nordic welfare states have the highest levels of social trust, while Poland is close to the average (Bergh \& Bjørnskov, 2011). Entrepreneurship research has also shown that trust has a positive influence on entrepreneurial orientation (Chuluunbaatar et al., 2011). The present study also explored whether general societal trust creates trust among individuals in their own abilities to be entrepreneurs.

\section{The Theory of Planned Behaviour}

The main concept of this study is entrepreneurial intention: a person's concrete plan or serious intention to start a firm in the near future. In the theory of planned behaviour (Ajzen, 1991), the term intention refers to specific action-intention - an intention to behave in a certain way or to perform a certain act. However, in the context of attitude discussion, intentions have been understood in different ways and are related not only to the actual intention, but also to the desirability of the object and how likely the person believes their attainment of the object to be (Armitage \& Conner, 2001). Because the study examined young people who did not yet have clear career plans, the concept of entrepreneurial intention refers also to a person's general desire or aspiration to become an entrepreneur, and not only to having a concrete action plan.

According to the theory of planned behaviour, behavioural intentions are impacted by three components: attitude towards behaviour, subjective norms, and perceived behavioural control (Ajzen, 1991, p. 182). Thus, young people's entrepreneurial intentions are influenced by their personal appreciation of entrepreneurship, the expectations of their peer circles, and their own perceptions of their capacity as entrepreneurs.

Attitude is a concept comprising many aspects and does not have a single consistent definition. Typically, it is defined as a psychological tendency expressed by evaluating a particular entity within some dimension (Eagly \& Chaiken, 1993). In traditional social psychology, attitude is understood, in particular, as a general valuation. Yet Ajzen's $(1991,2001)$ starting point is that attitudes always occur in a certain context, and so specific attitudes toward a specific activity, as opposed to general attitudes, must be studied. Moreover, entrepreneurship attitude may be understood in different ways. For example, the measure of personal attitude, according to Liñán and Chen (2009), is related to personal career choices. In contrast, the GEM study examined the general appreciation of respondent entrepreneurs. 
Ajzen (1991) argues that an assessment of specific attitudes may explain and predict behaviour more effectively than a consideration of general attitudes. However, there is a fundamental problem connected to Ajzen's conception of attitude: if all behaviours are linked with one's own attitude, the concept of attitude becomes too narrow, and its explanatory importance decreases. Indeed, this kind of attitude differs from the traditional concept of attitude. Therefore, the current study replaced Ajzen's (1991) idea of attitude with a general concept of attitude.

Perceived behavioural control is connected with how a young person estimates his or her own personal capacity to endure the different duties and responsibilities associated with entrepreneurial activities and with setting up an enterprise. It is based on Bandura's (1982) social learning theory and on the concept of perceived self-efficacy. Bandura also analysed the concept of outcome expectations, which, in the context of entrepreneurship, refers to how firmly young people believe they can achieve success as entrepreneurs. According to previous entrepreneurial intention research, perceived selfefficacy and outcome expectations are strongly interrelated (Rantanen \& Toikko, 2013), and there is no reason to consider them separately. Consequently, this study focused on perceived control, a combination of those two variables. The concept refers to people's self-belief in being able to cope with the responsibilities of working as an entrepreneur and being successful.

The concept of subjective norm represents the belief in how people closest to you value the desirability of a particular behaviour (Ajzen, 1991, 2001). In the case of young people, the subjective norm may refer especially to the expectations and wishes of one's parents and peer group. In addition, there is significance in the social context with which the young person associates his/her future business activity and whose valuations the young person considers important in that context.

Several comparative entrepreneurial studies have been based on the theory of planned behaviour. Moriano et al. (2012) found entrepreneurial intentions are higher in Poland than in some other European countries (e.g., Germany, The Netherlands, Spain); in addition, entrepreneurial attitudes and perceived behavioural control attain higher levels in Poland. According to Liñán and Chen (2009), the influence of entrepreneurial attitudes, subjective norms, and perceived behavioural control depends on the national level of individualism.

\section{Social Welfare Attitudes}

In this study, the theory of planned behaviour is complemented by two concepts relating to social welfare attitudes. First, the individual's responsibility is the perception that the individual is responsible for his own livelihood and for coping in different social situations. Typically, individual responsibility attribution is based on the internal causal attribution of social issues (e.g., the way of thinking that relates the reasons for unemployment, poverty, etc. to oneself). However, in a conceptual sense, it is one thing to talk about the reasons and another thing to talk about people's responsibility. Comparative studies indicate significant national differences in the attribution of social issues (Blomberg, Kallio \& Kroll, 2010).

The concept of trust can be understood in two senses: we can talk about general trust (e.g., "generally speaking, most people can be trusted") and political trust (the extent to which people trust political institutions) (Valdimarsdóttir, 2010). From the 
perspective of socio-political analysis, trust in government and institutions is an essential factor. According to Mishler and Rose (2001), trust in political institutions is vital to a democracy, but in post-communist countries, distrust of institutions is widespread. In this study, the concept of trust in society means that an individual can count on the support of government and institutions in various risk situations (unemployment, illness, poverty, etc.). In terms of new-venture creation, the importance of trust is twofold: on the one hand, trust in society creates a safe starting point for risk taking; on the other hand, a lack of trust may be a factor that forces one into self-employment.

\section{MATERIAL AND METHODS}

\section{Questions and Hypotheses}

Based on the results of the GEM study, we could assume that social political factors are also important from the perspective of entrepreneurial intention. European comparisons show that entrepreneurial intention is high in many post-communist Eastern European countries, and low in many Nordic welfare states (Xavier et al., 2013, p. 21). This study focuses on one post-communist country (Poland) and one Nordic country (Finland). Previous studies show that entrepreneurial intention can be explained using the attitude approach, particularly Ajzen's (1991) theory on planned behaviour. Thus, in this study the difference between Poland and Finland is analysed from the perspective of the theory of planned behaviour and social welfare attitudes.

This study addresses the following: How do Finnish and Polish young people's entrepreneurial attitudes and intentions differ? What social psychological factors explain young people's entrepreneurial intentions in Finnish and Polish societies? What is the significance of social welfare attitudes in terms of entrepreneurial intentions in Finland and Poland?

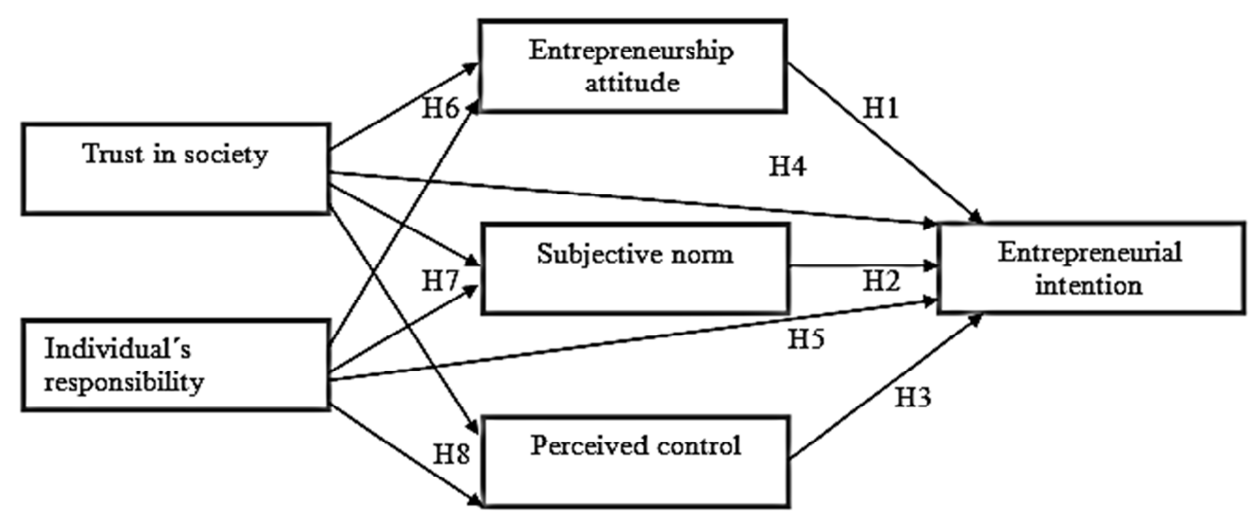

Figure 1. Research model

Source: own study.

Based on the theory of planned behaviour (Ajzen, 1991, 2001), the following three hypotheses will be tested (cf. Figure 1): 
H1: Entrepreneurship attitude has a positive impact on entrepreneurial intentions.

H2: Subjective norms have a positive impact on entrepreneurial intentions.

H3: Perceived control has a positive impact on entrepreneurial intentions.

In relation to social welfare attitudes, five hypotheses will be tested. Two refer to the direct impact of social welfare attitudes:

H4: Trust in society has a negative impact on entrepreneurial intentions.

H5: Individual responsibility attribution for social issues has a positive impact on entrepreneurial intentions.

The final three hypotheses refer to the indirect impact of social welfare attitudes:

H6: Entrepreneurship attitude depends (positively) on trust in society and (positively) on individual responsibility attribution for social issues.

H7: Subjective norm depends (positively) on trust in society and (positively) on individual responsibility attribution for social issues.

Perceived control depends (positively) on trust in society and (positively) on

H8: $\quad$ individual responsibility attribution for social issues.

This study targeted the Helsinki-Uusimaa region in southern Finland and the Wielkopolska region in Poland. Geographically, Uusimaa covers only $3 \%$ of Finland's land surface, but it accounts for about a third of the county's population and industrial production. The Uusimaa region consists of the Helsinki metropolitan area, as well as smaller cities and rural areas. Wielkopolska is situated in the central-western part of Poland; it is the second largest region in the country in terms of area, and third largest in terms of population. Wielkopolska is both an industrial and agricultural region. Its biggest city and capital is Poznań, which is home to about a sixth of the region's population.

\section{Samples}

The samples were collected in a real class environment in 2013. The Polish schools were chosen randomly from a list of all secondary schools in Wielkopolska, and the Polish sample was collected via a paper questionnaire. It was collected mostly by a PhD student from Poznań University of Economics, and partly by teachers from the schools. By contrast, the Finnish data was collected via an electronic survey, although for practical reasons the survey was completed on paper in one school. The survey was organized by school personnel, but a research assistant was involved in data collection and, if necessary, answered the students' questions about the survey. The respondents were mainly 17-18-year-olds. As data collection took place during school time, almost all of the students responded to the survey.

The Finnish sample $(\mathrm{N}=725)$ was drawn from six upper secondary schools and six vocational schools across eight municipalities in the region of Uusimaa. Participating from the vocational schools were cultural, economics, social and healthcare, technology, and transport departments. The intention was to include respondents from the whole region. Of the Finnish respondents, $68.4 \%$ were from the Helsinki metropolitan area (68.6\% in the population) and the rest were from elsewhere in the Uusimaa region. The proportion of Swedish-speaking respondents was $9.1 \%$ ( $8.5 \%$ in the population). The 
share of vocational school students was $40 \%$, which is close to the national average. Overall, the representativeness of the survey was satisfactory. In Finland, 90\% of 16-18year-olds study either in upper secondary school or in a vocational high school (City of Helsinki, 2009, p. 15), but after the age of 18 there is much more variation in young people's situations. Therefore, from the perspective of the sample's comprehensiveness, 17-18-years-olds were an optimal target group.

In Poland, it was important first to define the sample, which was done based on data from the General Statistics Bureau (Główny Urząd Statystyczny). This highlighted two essential features that differ Polish high schools - type of school and its localization. There are three statistically important types of high schools in Poland: secondary school (where $45 \%$ of all Polish high school students study), technical college (39.3\%), and vocational school (15.7\%). Young people are usually educated in urban areas (94.3\%) rather than in rural schools (5.7\%). From a list of all high schools in Wielkopolska, students were randomly chosen from thirteen urban schools in eight cities, and from three rural schools. Finally, 939 questionnaires were collected, of which 52 were rejected because of mistakes and a lack of answers. The structure of the survey sample was similar to the general population trend. It consisted of $47.8 \%$ secondary school students, $39.8 \%$ technical college students, and $12.4 \%$ vocational school students. Of these respondents, $94.2 \%$ were studying in urban schools and $5.7 \%$ in rural schools.

\section{Methods}

The data were analysed using normal statistical methods. First, the analysis was based on factor analysis, which was conducted using generalized least squares and varimax with Kaiser normalization. The analysis was carried out separately in both national groups. For the formation of sum variables, the questions with a factor loading of at least 0.5 were chosen into at least one of the two data. In practice, the factor analyses were to a large extent consistent in both national groups. The sum of the variable was constructed as an average of the variables. Cronbach's alpha coefficients were calculated. The reliabilities were mostly more than 0.8 , but the reliability of the variable "trust in society" was only 0.664 in the Finnish sample.

According to Clason \& Dormody (1994), there are no hard and fast rules for deciding how normal is normal enough in the case of Likert scales, and so it is necessary to make the decisions using different criteria. In this study, the normality of distributions was evaluated using the Kolmogorov-Smirnov test and histograms. The distributions for all variables (e.g., entrepreneurial intention) were not completely normal. However, parametric methods were used because the distributions were nonetheless close to normal and the size of the data set was sufficient.

Statistical analyses were conducted using t-test and linear regression analysis with the Backward method. Background variables (gender, entrepreneurial family) were examined as dummy variables. Before carrying out regression analyses, the validity of the conditions were checked (the normality of the residuals' distributions, the linearity condition, and multi-co-linearity between the independent variables/VIF coefficients). In the case of some regression analysis, the $\mathrm{R}$ squared coefficient was very low. When selecting the analysis method, a variety of methods were tested (exponential, logarithmic, square, cubic analysis). None of the alternative methods offered a 
significantly better explanation than linear regression analysis and graphically examined the interrelation of the variables were close to linear.

In all, there are a number of general methodological issues related to the use of Likert-type scales. It is clear that the Likert scale is, in the statistical mind, only ordinal. However, a number of researchers (e.g., Norman, 2010) have suggested that parametric methods can be utilized in the case of Likert scales without concern for obtaining incorrect answers. Clason and Dormody (1994) argue that it is not a question of right and wrong ways to analyse data from Likert-type items; the issue relates more to answering the research questions meaningfully.

In this paper, the interpretation of the results was based on a $1 \%$ significance level $(p<0.01)$. During the survey, there were no unexpected problems concerning the questionnaire, its questions, or answering.

\section{Measures}

The questionnaire contained 89 questions, the majority of which were Likert-type scale items ( 1 = "Strongly disagree" to $5=$ "Strongly agree"). According to Armitage and Conner's (2001) meta-analyses, the variables of the theory of planned behaviour have been examined using a number of different measures. In this study, the questions related to entrepreneurial attitude, subjective norms, perceived control, and entrepreneurial intentions were based on a previous attitude study among Finnish young people (Rantanen \& Toikko, 2013). The measure of entrepreneurial intentions was formed from four questions connected not only to the actual intention, but also to entrepreneurial willingness and an assessment of the likelihood of the career choice in entrepreneurship.

Questions referring to entrepreneurship attitude related to general perception of entrepreneurship, not to behavioural attitude. Questions related to the value of entrepreneurs and entrepreneurs' work, as well as their societal significance. The measure of perceived control contained issues related to young people's confidence in their own abilities to be an entrepreneur and to succeed as an entrepreneur. Questions about subjective norm related to the normative expectations of parents, friends, professional field, and close environment in general. Sum variables were constructed using factor analysis.

Social welfare attitudes were examined using different measures. In previous attitude studies, the issues attached to responsibility attribution have been related, for example, to responsibility of state (Valdimarsdóttir, 2010) and causal and blame attributions for poverty (e.g., Bullock, 2004; Blomberg et al., 2010). They have also used a variety of measures of trust in social attitude studies. For example, Valdimarsdóttir (2010) looked separately at general (interpersonal) trust and political trust.

In this study, social welfare attitudes were examined using twenty intentionally prepared questions. The final measure of social welfare attitudes included twelve issues, loaded on two factors: individual responsibility and trust in society. The measure of an individual's responsibility contained issues relating to the customers of social welfare (e.g., People who receive social welfare are lazy) and to people's own responsibility for social problems (e.g., If someone is unemployed, it is his/her own choice). In turn, the measure of trust in society contained issues relating to trust in government (e.g., I trust the government to take care of people who can't take care of themselves). The 
reliabilities of the constructed variables were satisfactory (cf. Table 1), and distributions were nearly normal.

Table 1. Sum Variables (Cronbach's alpha, correlation with intention, mean, Sd, t-value)

\begin{tabular}{|c|c|c|c|c|c|c|c|c|}
\hline Variable & Country & $\mathbf{N}$ & Items & Alpha & Pearson & Mean & Sd & $\mathbf{t}$ \\
\hline \multirow{2}{*}{$\begin{array}{l}\text { Entrepreneurial } \\
\text { intention }\end{array}$} & Finland & 723 & 4 & 0.899 & - & 2.73 & 1.00 & \multirow{2}{*}{$18.46 * * *$} \\
\hline & Poland & 887 & 4 & 0.869 & - & 3.68 & 1.06 & \\
\hline \multirow{2}{*}{$\begin{array}{l}\text { Entrepreneurship } \\
\text { attitude }\end{array}$} & Finland & 722 & 4 & 0.705 & $0.272 * * *$ & 3.61 & 0.63 & \multirow{2}{*}{$17.02 * * *$} \\
\hline & Poland & 887 & 4 & 0.725 & $0.165 * * *$ & 2.99 & 0.83 & \\
\hline \multirow{2}{*}{ Subjective norm } & Finland & 723 & 5 & 0.820 & $0.750 * * *$ & 2.91 & 0.82 & \multirow{2}{*}{$2.88^{* *}$} \\
\hline & Poland & 887 & 5 & 0.830 & $0.569 * * *$ & 3.04 & 0.99 & \\
\hline \multirow{2}{*}{ Perceived control } & Finland & 723 & 7 & 0.933 & $0.674 * * *$ & 3.30 & 0.94 & \multirow{2}{*}{$13.83 * * *$} \\
\hline & Poland & 887 & 7 & 0.917 & $0.601 * * *$ & 3.93 & 0.87 & \\
\hline \multirow{2}{*}{$\begin{array}{l}\text { Individual's } \\
\text { responsibility }\end{array}$} & Finland & 720 & 8 & 0.835 & $0.152 * * *$ & 2.63 & 0.73 & \multirow{2}{*}{1.00} \\
\hline & Poland & 887 & 8 & 0.845 & 0.053 & 2.59 & 0.88 & \\
\hline \multirow{2}{*}{ Trust in society } & Finland & 721 & 4 & 0.664 & -0.011 & 3.33 & 0.67 & \multirow{2}{*}{$18.89 * * *$} \\
\hline & Poland & 887 & 4 & 0.867 & $-0.076^{*}$ & 2.56 & 0.96 & \\
\hline
\end{tabular}

Note: ${ }^{*} \mathrm{p}<0.05 ;{ }^{* *} \mathrm{p}<0.01 ;{ }^{* * *} \mathrm{p}<0.001$. The control variables were gender $(0=$ Female, $1=$ Male) and entrepreneurial family history (Is either of your parents (or some other member of your family) an entrepreneur?; $0=$ No, $1=$ Yes) in both samples.

Source: own study.

\section{RESULTS AND DISCUSSION}

\section{Entrepreneurial Intentions and Entrepreneurial Attitude}

The issues related to entrepreneurial intention and the distribution of participants' responses are shown in Table 2.

Table 2. Questions about Entrepreneurial Intentions

\begin{tabular}{|c|c|c|c|c|c|c|c|c|}
\hline \multirow{2}{*}{ Question } & \multirow{2}{*}{$\begin{array}{l}\text { Coun- } \\
\text { try }\end{array}$} & \multirow{2}{*}{$\mathbf{N}$} & \multirow{2}{*}{$\begin{array}{l}\text { Agree } \\
\text { (in \%) }\end{array}$} & \multirow{2}{*}{$\begin{array}{l}\text { Dis- } \\
\text { agree } \\
\text { (in \%) }\end{array}$} & \multirow{2}{*}{ Mean } & \multirow{2}{*}{ Sd } & \multicolumn{2}{|c|}{ Difference } \\
\hline & & & & & & & $\mathbf{t}$ & Sig \\
\hline \multirow{2}{*}{$\begin{array}{l}\text { If I could freely choose, I'd } \\
\text { rather be an entrepreneur } \\
\text { than an employee }\end{array}$} & Finland & 723 & 38.7 & 31.7 & 3.08 & 1.20 & \multirow{2}{*}{14.53} & \multirow{2}{*}{0.000} \\
\hline & Poland & 887 & 69.3 & 14.9 & 3.98 & 1.28 & & \\
\hline \multirow{2}{*}{$\begin{array}{l}\text { My aim is to become an } \\
\text { entrepreneur in the future }\end{array}$} & Finland & 722 & 23.3 & 40.0 & 2.70 & 1.15 & \multirow{2}{*}{12.51} & \multirow{2}{*}{0.000} \\
\hline & Poland & 887 & 49.6 & 20.6 & 3.45 & 1.25 & & \\
\hline \multirow{2}{*}{$\begin{array}{l}\text { I am going to make a living } \\
\text { as an entrepreneur }\end{array}$} & Finland & 721 & 15.7 & 44.0 & 2.52 & 1.10 & \multirow{2}{*}{16.37} & \multirow{2}{*}{0.000} \\
\hline & Poland & 887 & 50.5 & 20.5 & 3.48 & 1.25 & & \\
\hline \multirow{2}{*}{$\begin{array}{l}\text { For me, entrepreneurship } \\
\text { is a probable career choice }\end{array}$} & Finland & 723 & 19.9 & 41.9 & 2.62 & 1.11 & \multirow{2}{*}{20.37} & \multirow{2}{*}{0.000} \\
\hline & Poland & 887 & 66.6 & 15.8 & 3.80 & 1.21 & & \\
\hline
\end{tabular}

Source: own study.

First, the comparative analysis showed that Polish young people had a stronger desire to become entrepreneurs than Finnish young people. For example, $70 \%$ of Polish respondents agreed that, "If I could freely choose, I'd rather be an entrepreneur than an employee," with only $39 \%$ of Finnish respondents agreeing. Half of the Polish 
respondents planned to make a living as entrepreneurs, while only $16 \%$ of the Finns planned to do so. Next, entrepreneurial attitudes were analysed (cf. Table 3).

According to the results, Finnish young people have a quite positive attitude towards entrepreneurship. For example, $38 \%$ of respondents agreed with the statement, "Entrepreneurs are ideal citizens," and 12\% disagreed. In contrast, nearly half of Polish young people disagreed with the statement, and only $13 \%$ agreed with it.

Table 3. Questions about Entrepreneurial Attitudes

\begin{tabular}{|c|c|c|c|c|c|c|c|c|}
\hline \multirow{2}{*}{ Question } & \multirow{2}{*}{ Country } & \multirow{2}{*}{$\mathbf{N}$} & \multirow{2}{*}{$\begin{array}{l}\text { Agree } \\
\text { (in \%) }\end{array}$} & \multirow{2}{*}{$\begin{array}{c}\text { Disagree } \\
\text { (in \%) }\end{array}$} & \multirow{2}{*}{ Mean } & \multirow{2}{*}{ Sd } & \multicolumn{2}{|c|}{ Difference } \\
\hline & & & & & & & $t$ & Sig \\
\hline \multirow{2}{*}{$\begin{array}{l}\text { Entrepreneurs are ideal } \\
\text { citizens }\end{array}$} & Fin & 722 & 37.7 & 12.2 & 3.31 & 0.87 & \multirow{2}{*}{17.42} & \multirow{2}{*}{0.000} \\
\hline & Poland & 887 & 13.4 & 47.6 & 2.45 & 1.11 & & \\
\hline \multirow{2}{*}{$\begin{array}{l}\text { Entrepreneurs are typically } \\
\text { hard-working and responsible }\end{array}$} & Finland & 722 & 61.6 & 5.4 & 3.75 & 0.85 & \multirow{2}{*}{14.25} & \multirow{2}{*}{0.000} \\
\hline & Poland & 887 & 36.8 & 30.3 & 3.04 & 1.15 & & \\
\hline \multirow{2}{*}{$\begin{array}{l}\text { Entrepreneurs' work is } \\
\text { valuable for society as a whole }\end{array}$} & Finland & 722 & 68.6 & 5.1 & 3.90 & 0.88 & \multirow{2}{*}{12.60} & \multirow{2}{*}{0.000} \\
\hline & Poland & 887 & 43.4 & 21.3 & 3.28 & 1.09 & & \\
\hline \multirow{2}{*}{$\begin{array}{l}\text { Entrepreneurs play a key role } \\
\text { in societal success }\end{array}$} & Finland & 721 & 43.7 & 8.3 & 3.47 & 0.87 & \multirow{2}{*}{6.01} & \multirow{2}{*}{0.000} \\
\hline & Poland & 887 & 37.0 & 24.4 & 3.17 & 1.13 & & \\
\hline
\end{tabular}

Source: own study.

\section{What Factors Explain Entrepreneurial Intentions?}

A linear regression analysis was employed to examine the factors that explain entrepreneurial intention (cf. Table 4). The share explanation of this regression analysis was quite good ( $R$ square was 0.638 in the Finnish sample and 0.492 in the Polish sample).

Table 4. Regression analysis. Dependent variable: Entrepreneurial intention

\begin{tabular}{|c|c|c|c|c|c|c|}
\hline \multirow[t]{2}{*}{ Independent variable } & \multicolumn{3}{|c|}{$\begin{array}{c}\text { Finnish Data } \\
\left(\mathrm{R}^{2}=63.8 \% ; \mathrm{F}=250.7 ; \mathrm{p}=.000\right)\end{array}$} & \multicolumn{3}{|c|}{$\begin{array}{c}\text { Polish Data } \\
\left(R^{2}=49.2 \% ; F=285.0 ;\right. \\
p=.000)\end{array}$} \\
\hline & Beta & $t$ & Sig & Beta & $t$ & Sig \\
\hline Entrepreneurial attitude & -0.052 & -2.05 & 0.040 & - & - & - \\
\hline Subjective norm & 0.550 & 17.84 & 0.000 & 0.390 & 14.90 & 0.000 \\
\hline Perceived control & 0.341 & 11.17 & 0.000 & 0.441 & 16.83 & 0.000 \\
\hline Trust in society & -0.105 & -4.45 & 0.000 & - & - & - \\
\hline Individual's responsibility & 0.060 & 2.61 & 0.009 & - & - & - \\
\hline Gender & - & - & - & 0.044 & 1.81 & 0.071 \\
\hline Entrepreneurial family history & - & - & - & - & - & - \\
\hline
\end{tabular}

Source: own study.

The analysis shows that the subjective norms and perceived control explain entrepreneurial intentions quite well. In the case of the Polish sample, there were no other significant relationships. In the Finnish sample, trust in society also explains entrepreneurial intentions. Thus, hypotheses $\mathrm{H} 2$ and $\mathrm{H} 3$ are supported. In contrast, hypothesis $\mathrm{H} 1$ is not supported by the data. Hypotheses $\mathrm{H} 4$ and $\mathrm{H} 5$ are supported by the Finnish data, but not the Polish data. 
Perceived control is higher among Polish than Finnish young people (Table 1). For example, $62 \%$ of Polish young people agreed with the statement, "I believe I could succeed as an entrepreneur," but only $50 \%$ of Finns agreed with it; $72 \%$ of Poles and $49 \%$ of Finns trust they are capable of working as small business owners. There is also a significant difference in subjective norms, but this difference is quite small (cf. Table 1). Hence, part of the national difference in entrepreneurial intentions can be explained by the difference in perceived control.

The results are consistent with the theory of planned behaviour; there is no significant $(p<0.01)$ connection between entrepreneurship attitude and entrepreneurial intentions. This is not surprising, because this study examined people's general entrepreneurship attitudes, not their attitudes toward their own activities.

\section{What Is the Indirect Impact of Social Welfare Attitudes?}

In the case of individual responsibility attribution, the samples do not differ significantly (cf. Table 1). In the Polish sample, young people's trust in society is much lower than in the Finnish sample. For example, $41 \%$ of Finnish respondents and only $15 \%$ of Polish respondents agree with the statement, "If I need help, I believe the government will take care of me." Half of Finnish and only $16 \%$ of Polish respondents trust the government to take care of people who cannot take care of themselves. Next, regression analysis was

Table 5. Indirect affect of social welfare attitudes, Regression analyses

\begin{tabular}{|c|c|c|c|c|c|c|c|}
\hline \multirow{2}{*}{$\begin{array}{l}\text { Dependent } \\
\text { variable }\end{array}$} & \multirow{2}{*}{$\begin{array}{l}\text { Independent } \\
\text { variables }\end{array}$} & \multicolumn{3}{|c|}{ Finnish Data } & \multicolumn{3}{|c|}{ Polish Data } \\
\hline & & Beta & $\mathbf{t}$ & Sig. & Beta & $\mathbf{t}$ & Sig. \\
\hline \multirow{5}{*}{$\begin{array}{l}\text { Entreprene } \\
\text { urship } \\
\text { attitude }\end{array}$} & & \multicolumn{3}{|c|}{$\left(R^{2}=8.2 \% ; F=16.0 ; p=.000\right)$} & \multicolumn{3}{|c|}{$\left(R^{2}=7.4 \% ; F=23.5 ; p=.000\right)$} \\
\hline & Trust in society & 0.227 & 6.31 & 0.000 & 0.171 & 5.22 & 0.000 \\
\hline & $\begin{array}{l}\text { Individual's } \\
\text { responsibility }\end{array}$ & 0.126 & 3.35 & 0.001 & 0.164 & 4.97 & 0.000 \\
\hline & Gender & -0.073 & -1.94 & 0.052 & - & - & - \\
\hline & $\begin{array}{l}\text { Entrepreneurial } \\
\text { family history }\end{array}$ & 0.132 & 3.66 & 0.000 & 0.091 & 2.79 & 0.005 \\
\hline \multirow{5}{*}{$\begin{array}{l}\text { Subjective } \\
\text { norm }\end{array}$} & & \multicolumn{3}{|c|}{$\left(R^{2}=8.1 \% ; F=15.7 ; p=.000\right)$} & \multicolumn{3}{|c|}{$\left(R^{2}=3.3 \% ; F=15.1 ; p=.000\right)$} \\
\hline & Trust in society & 0.097 & 2.69 & .007 & - & - & - \\
\hline & $\begin{array}{l}\text { Individual's } \\
\text { responsibility }\end{array}$ & 0.063 & 1.66 & .097 & .113 & 3.39 & 0.001 \\
\hline & Gender & 0.119 & 3.14 & .002 & - & - & - \\
\hline & $\begin{array}{l}\text { Entrepreneurial } \\
\text { family history }\end{array}$ & 0.227 & 6.30 & .000 & .132 & 3.98 & 0.000 \\
\hline \multirow{5}{*}{$\begin{array}{l}\text { Perceived } \\
\text { control }\end{array}$} & & \multicolumn{3}{|c|}{$\left(R^{2}=8.4 \% ; F=16.4 ; p=.000\right)$} & \multicolumn{3}{|c|}{$\left(R^{2}=2.7 \% ; F=8.2 ; p=.000\right)$} \\
\hline & Trust in society & 0.184 & 5.10 & 0.000 & -0.115 & -3.45 & 0.001 \\
\hline & $\begin{array}{l}\text { Individual's } \\
\text { responsibility }\end{array}$ & 0.066 & 1.74 & 0.082 & - & - & - \\
\hline & Gender & 0.145 & 3.86 & 0.000 & 0.100 & 2.99 & 0.003 \\
\hline & $\begin{array}{l}\text { Entrepreneurial } \\
\text { family history }\end{array}$ & 0.152 & 4.23 & 0.000 & 0.066 & 1.99 & 0.047 \\
\hline
\end{tabular}

Source: own study. 
used to determine how these social welfare attitudes impact on entrepreneurial attitudes, subjective norm, and perceived control (cf. Table 5).

In contrast, the Polish sample subjective norm depends positively on individuals' responsibility, and perceived control depends negatively on trust in society (cf. Figure 2 ).

The results reveal that the indirect impact of social welfare attitudes on entrepreneurial intention is quite low. Explanation shares of regression analyses are minor in both samples. Second, the significance of social welfare attitudes is entirely different for the Finnish and Polish samples. Hypothesis $\mathrm{H} 6$ is supported. In contrast hypothesis $\mathrm{H} 7$ is partially valid in both samples and hypothesis $\mathrm{H} 8$ is partially valid only in Finnish sample.

Analysis of the Finnish data suggests that in terms of young people's entrepreneurial intention, the importance of societal trust is dualistic. According to linear regression analysis, the direct influence of trust is negative. On the other hand, the dependence between trust in society and perceived control is positive and significant, likewise the dependence between trust in society and perceived control. Hence, trust in society has a positive indirect effect on entrepreneurial intentions. The total influence of these two is neutral: the correlation between trust in society and entrepreneurial intentions is not significant (cf. Table 1).

Finland:
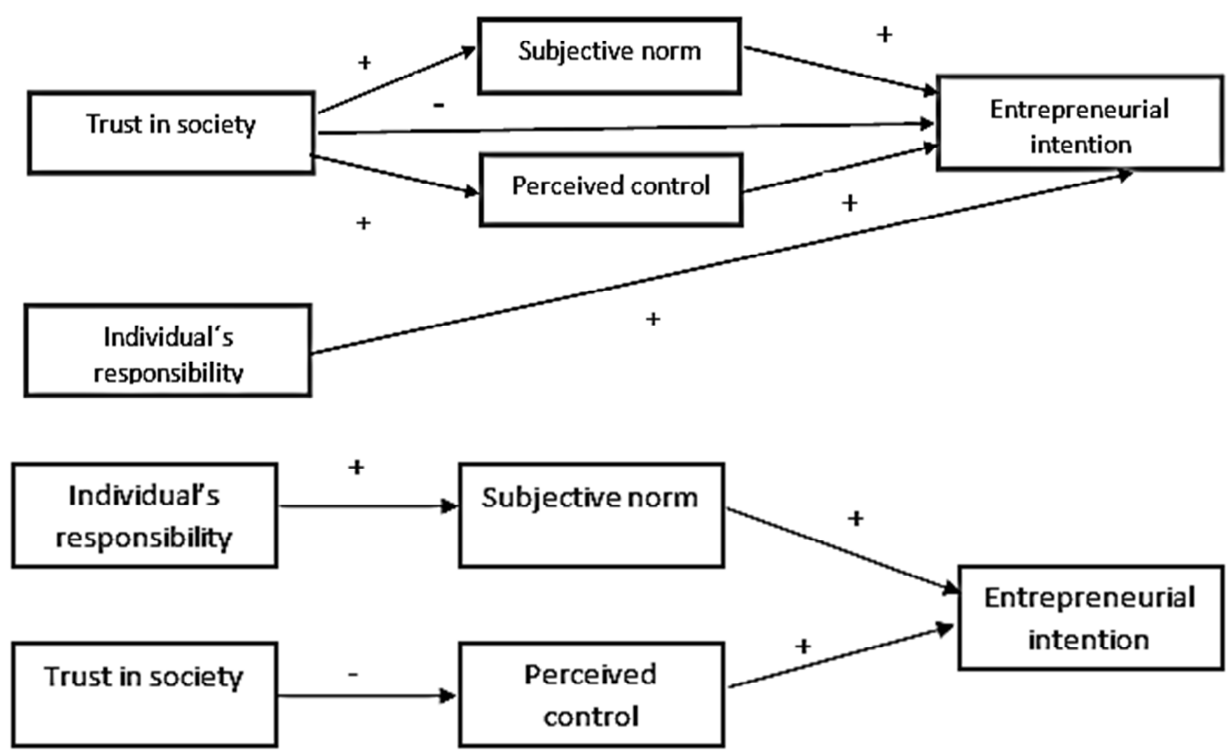

Figure 2. Final model of the study (without control variables)

Source: own study. 


\section{CONCLUSIONS}

According to this study, Finnish and Polish young people approach entrepreneurship in quite different ways. Consistent with the Global Entrepreneurship Monitor (Xavier et al., 2013), Polish young people's entrepreneurial intentions are much stronger, and their entrepreneurial attitude much lower, than Finns. This means that Finnish young people appreciate entrepreneurs at a general level, but do not consider becoming entrepreneurs themselves, while the Poles think about entrepreneurship in the opposite manner. In addition, the results show that subjective norms and perceived control are central factors in explaining entrepreneurial intention, which is consistent with Ajzen's $(1991,2001)$ theory. The national differences in intentions can be explained by perceived control. Polish young people trust their own abilities to cope with the entrepreneur's role and to succeed as entrepreneurs (cf. Moriano et al., 2012), while Finns do not rely on their own abilities to such an extent.

Consistent with previous studies (Bergh \& Bjørnskov, 2011; Kumlin \& Rothstein, 2005; Nannestad, 2008), the results also show that Finnish people's trust in society is much stronger than that of the Polish participants. Furthermore, the relationship between social welfare attitudes and entrepreneurial intention in Finland is different from that in Poland. In the case of Finland, the influence of general trust is dualistic; the direct influence of high trust in society is negative, but indirect influence via perceived control is positive. In the case of Poland, the influence of trust is negative and only indirect. In addition, it seems that the emphasis of individual responsibility and the expectations of close relatives or peers are positively associated with each other among Polish young people.

However, the differences in individuals' attitudes and cognition seem insufficient to explain national differences in attitudes toward entrepreneurship and entrepreneurship intentions. In contrast, the social analysis may help to understand national differences. An explanation for the national differences is associated with differences in the individual-state relationship, which can be presented as strong or weak in nature.

In Finland, individuals have a strong relationship with the state, which is based on the Nordic welfare ideology of collective responsibility and individuality. The strong individual-state relationship is built through the well-established education system (e.g., Antikainen, 2010), social security, and a highly regulated labor market. On the other hand, social justice and democracy are the key principles of the Nordic welfare model, which supports the idea of individuality. In the Finnish context, young people who trust the state also trust themselves and vice versa (cf. Rothstein, 2005; Uslaner, 2002, pp. 104-105). Thus, social trust increases young people's confidence in their own abilities to cope and succeed as entrepreneurs, as demonstrated in the results of this study. In this sense, trust in the society and trust in the person are related, which is a core phenomenon of the strong individual-state relationship. However, the strong individualsociety relationship reduces young people's need to set up their own businesses, even though they see entrepreneurship as an important part of the societal structures and institutions.

The Polish society represents young capitalism in which state structures lack the rigidity, and young people's relationships with the state lack the intensity, of those found 
in Finland. The society is not expected to provide welfare and well-being, but each individual is supposed to struggle independently for his or her future (cf. Lee, 2013). And so the weak individual-society relationship supports young people's confidence in their own abilities and skills, and thus it also encourages them to be entrepreneurs (Neace, 1999). In contrast, trust in society reduces young people's confidence in their own abilities to be entrepreneurs. In this sense, trust in society and trust in one's own abilities seem to mean opposite things in Poland.

Overall, supporting young people's entrepreneurship intentions will be a key issue for the future of both countries. According to this study, influencing young people's confidence in their abilities and skills is more important than trying to influence general attitudes about entrepreneurship. Thus, entrepreneurship education has a key role in supporting young people's entrepreneurship. Furthermore, national differences in intentions, as well as an appreciation of entrepreneurship, can be explained by societal and historical factors. Therefore promoting entrepreneurship is linked with general civic education (cf. Ikonen, 2006). On the other hand, social support received from family and significant others has a positive impact on young people's intentions to become entrepreneurs.

There are some limitations with respect to the results of this study. First, the analysis was based on only Finnish and Polish data. Therefore, the results cannot be generalized directly to other countries. Much more research and social analysis is required to demonstrate the relationship between societal factors and entrepreneurial intentions. Second, the study examined only a few social variables (trust in society and responsibility attribution of social issues). Although these are important, many other social factors can influence entrepreneurship.

Finally, it should be noted that, within the context of new ventures, the importance of intentions is limited. Real entrepreneurial capabilities, new business opportunities and their identification, as well as a variety of economic factors, play a key role. In addition, the long temporal distance between the time of the survey and the realization of the actual behaviour (new venture creation) may reduce the suitability of using intentions to predict future behaviour. However, such intentions are an important individual-level factor in creating a new business, and are thus worthy of attention.

\section{REFERENCES}

Aidukaite, J. (2009). Old welfare states and new welfare regimes in Eastern Europe: Challenges or implications? Communist and Post-Communist Studies, 42, 23-39.

Ajzen, I. (1991). The theory planned behaviour. Organizational Behavior and Human Decision Process, 50, 179-211.

Ajzen, I. (2001). Nature and operation of attitudes. Annual Reviews Psychology, 52, 27-58.

Alestalo, M., \& Kuhnle, S. (1987). The Scandinavian route: economic, social and political developments in Denmark, Norway and Sweden. In R. Erikson, J. E. Hansen, S. Ringen, \& H. Uusitalo (Eds.), The Scandinavian Model. Welfare States and Welfare Research (pp. 3-38). New York and London: M.E. Sharpe.

Alestalo, M., Hort, S., \& Kuhnle, S. (2009). The Nordic model: Conditions, origins, outcomes, lessons. Hertie School of Governance, Working Papers 41. 
Andreotti, A., Mingione, E., \& Polizzi, E. (2011). Local welfare systems: a challenge for social cohesion. DOI://www.socialpolis.eu/uploads/tx_sp/EF01_Paper.pdf

Antikainen, A. (2010). The capitalist state and education: The case of restructuring the Nordic model. Current Sociology, 58(4), 530-550.

Anttonen, A., \& Sipilä, J. (2012). Universalism in the British and Scandinavian social policy debates. In A. Anttonen, L. Häikiö, \& K. Stefánsson (Eds.), Welfare state, universalism and diversity (pp. 16-41). Cheltenham: Edward Elgar.

Armitage, C.J., \& Conner, M. (2001) Efficacy of the Theory of Planned Behaviour: A meta-analytic review. British Journal of Social Psychology, 40, 471-499.

Bandura, A. (1982). Self-efficacy mechanism in human agency. American Psychologist, 37, 122-147.

Bergh, A., \& Bjørnskov, C. (2011). Historical trust levels predict the current size of the welfare state. KYKLOS, 64(1), 1-19.

Blomberg, H., Kallio, J., \& Kroll, C. (2010). Sosiaalityöntekijöiden mielipiteet köyhyyden syistä Pohjoismaissa. Yhteiskuntapolitiikka, 75(6), 589-602.

Chuluunbaatar, E., Ottavia, D.B.L., \& Kung, S.-F. (2011). The entrepreneurial start-Up Process: The role of social capital and the social economic condition. Asian Academy of Management Journal, 16(1), 43-71.

City of Helsinki (2009). Nuorten koulutus Helsingissä. Tilastoja 38, Helsinki.

Draxler, J., \& Van Vliet. O. (2010). European social model: No convergence from the East. Journal of European Integration, 32(1), 115-135.

Eagly, A.H., \& Chaiken, S. (1993). The psychology of attitudes. Fort Worth, TX: Harcourt Brace Jovanovich.

Esping-Andersen, G. (1990). The three worlds of welfare capitalism. Cambridge: Polity Press.

Fitzpatrick, T. (2011). Welfare theory. An introduction to the theoretical debates in social policy. Basingstoke: Palgrave Macmillan.

Fitzsimmons, J., \& Douglas, E. (2005). Entrepreneurial Attitudes and Entrepreneurial Intentions: A Cross-Cultural Study of Potential Entrepreneurs in India, China, Thailand and Australia. Babson-Kauffman Entrepreneurial Research Conference, Wellesley, MA. June 2005.

Freytag, A., \& Thurik, R. (2007). Entrepreneurship and its determinants in a cross-country setting. Journal of Evolutionary Economics, 17, 117-131.

Goethner, M., Obschonka, M., Silbereisen, R.K., \& Cantner, U. (2012). Scientists' transition to academic entrepreneurship: Economic and psychological determinants. Journal of Economic Psychology, 33, 628-64.

Gorodnichenko, Y., \& Roland, G. (2012). Understanding the Individualism-Collectivism Cleavage and its Effects: Lessons from Cultural Psychology. In M. Aoki, T. Kuran, \& G. Roland, (Eds.), Institutions and Comparative Economic Development (pp. 213-236). International Economics Association, Hampshire: Palgrave Macmillan.

Hofstede, G. (1980). Motivation, leadership and organization: Do American theories apply abroad? Organizational Dynamic, 9(1), 42-63.

Ikonen, R. (2006). Yrittäjyyskasvatus, Kansalaisen taloudellista autonomiaa etsimässä, SoPhi 102, Jyväskylä, Minerva.

Krueger, N.F. Jr., Reilly, M.D., \& Carsrud, A.L. (2000). Competing models of entrepreneurial intentions. Journal of Business Venturing, 15, 411-432.

Kumlin, S., \& Rothstein, B. (2005). Making and breaking social capital: the impact of welfare state institutions. Comparative Political Studies, 38, 339-365. 
Le Grand, J. (2003). Motivation, Agency, and Public Policy of Knights, Knaves, Pawns and Queens. Oxford: Oxford University Press.

Le Grand, J. (2010). Knights and knaves return: public service motivation and the delivery of public services. International Public Management Journal, 13(1), 56-71.

Lee, C.S. (2013). Welfare states and social trust. Comparative Political Studies, 46(5), 603-630.

Lee, S.M., \& Peterson, S. (2000). Culture, entrepreneurial orientation, and global competitiveness. Journal of World Business, 35(4), 401-416.

Liñán, F. (2008). Skill and value perceptions: how do they affect entrepreneurial intentions? International Entrepreneurship and Management Journal, 4, 257-272.

Liñán, F., \& Chen, Y.W. (2009). Development and cross-cultural application of a specific instrument to measure entrepreneurial intentions. Entrepreneurship Theory and Practice, 33(3), 593-617.

Liñán, F., \& Santos, F.J. (2007). Does social capital affect entrepreneurial intentions? International Advances in Economic Research, 13, 443-453.

Mishler, W., \& Rose, R. (2001). What are the origins of political trust? Testing institutional and cultural theories in post-communist societies. Comparative Political Studies, 34(1), 30-63.

Mitchell, R.K., Smith, B., Seawright, K., \& Morse, E.A. (2000). Cross-cultural cognitions and venture creation: decision. Academy of Management Journal, 43, 974-993.

Moreno, L. (2010). Welfare mix, CSR and social citizenship. International Journal of Sociology and Social Policy 30, 683-696.

Moriano, J.A., Gorgievski, M., Laguna, M., Stephan, U., \& Zarafshani, K. (2012). A cross-cultural approach to understanding entrepreneurial intention. Journal of Career Development, 39(2), 162-185.

Mueller, S.L. (2004), Gender Gaps in Potential for Entrepreneurship A cross Countries and Cultures. Journal of developmental entrepreneurship, 9(3), 199-220.

Mueller, S.L. \& Thomas, A.S. (2001) Culture and entrepreneurial potential: A nine country study of locus of control and innovativeness. Journal of Business Venturing, 16(1), 51-75.

Nannestad, P. (2008). New work on trust: what have we learnt, if anything? Annual Review of Political Science, 11, 413-436.

Neace, M.B. (1999) Entrepreneurs in emerging economies. Creating trust, social capital and civil society. The ANNALS of the American Academy of Political and Social Science, 565(1), 148-161.

Noorderhaven, N., Thurik, R., Wennekers, S., \& van Stel, A. (2004). The Role of Dissatisfaction and per Capita Income in Explaining Self-Employment across 15 European Countries. Entrepreneurship Theory and Practice, 28, 447-466.

Rantanen, T., \& Toikko, T. (2013). Scandinavian Social values, attitudes and young people's entrepreneurial intention: a Finnish contribution. China-USA Business Review, 12(4), 349-360.

Rothsten, B. (2005). Social traps and the problem of trust. Cambridge: Cambridge University Press.

Siu, W.S., \& Lo, E.S.C. (2013). Cultural contingency in the cognitive model of entrepreneurial intention. Entrepreneurship Theory and Practice, 37(2), 147-173.

Tiessen, J.H. (1997). Individualism, collectivism, and entrepreneurship: A framework for international comparative research. Journal of Business Venturing, 12, 367-384.

Uslaner, E.M. (1999). Democracy and social capital. In M.E. Warren (Ed.), Democracy \& trust. Cambridge: Cambridge University Press, 121-150.

Valdimarsdóttir, M. (2010) Welfare state attitudes. Characteristics associated with individual support for governmental redistribution. Rannsóknir í félagsvísindum XI. Erindi flutt á ráđstefnu í október 2010, Ritrýnd grein, Reykjavík: Félagsvísindastofnun Háskóla Î́lands. 
Walker, J.K., Jeger, M., \& Kopecki, D. (2013). The role of perceived abilities, subjective norm and intentions in entrepreneurial activity. The Journal of Entrepreneurship, 22(2), 181-202.

Xavier, S., Roland, D.K., Jacqui K., Herrington, M., \& Vorderwulbecke, A. (2013). Global entrepreneurship monitor 2012 Global Report. Babson, Universidad del Desarrollo \& University Tun Abdul Razak. GEM.

\section{Authors}

The contribution of co-authors is equal and can be expressed as $1 / 3$ each of the authors.

\section{Teemu Rantanen}

Principal Lecturer in Laurea University of Applied Sciences (Finland); PhD in Social Psychology (University of Helsinki, Finland); Adjunct Professor (University of Helsinki, Finland).

\section{Agnieszka Pawlak}

PhD candidate in Department of International Competitiveness at Poznań University of Economics.

\section{Timo Toikko}

Principal Lecturer in Seinäjoki University of Applied Sciences (Finland); PhD in Social Work (Tampere University, Finland); Adjunct Professor (University of Jyväskylä, Finland).

\section{Correspondence to:}

Dr. Teemu Rantanen

Laurea University of Applied Sciences

Ratatie 22, Vantaa, Finland

teemu.rantanen@laurea.fi

\section{Copyright and License}

This article is published under the terms of the Creative Commons Attribution - NonCommercial - NoDerivs (CC BY-NC-ND 3.0) License http://creativecommons.org/licenses/by-nc-nd/3.0/ 